\title{
Influence of proteinuria on vascular disease, blood pressure, and lipoproteins in insulin dependent diabetes mellitus
}

\begin{abstract}
Patients with insulin dependent diabetes mellitus who develop proteinuria may die prematurely, whereas those who do not develop this complication have a comparatively normal life span. The excess mortality in diabetics with proteinuria is from cardiovascular as well as renal disease, but the reason is unclear. Risk factors for vascular disease were therefore assessed in 22 insulin dependent diabetics with proteinuria, but not renal failure, who were matched for sex, age, duration of diabetes, and glycated haemoglobin $\left(\mathrm{HbA}_{1}\right)$ values with a similar number who had normal urinary albumin excretion rates.

Macrovascular disease (ischaemic heart disease and peripheral vascular disease) was present in 10 patients with proteinuria but in only three with normal albumin excretion rates, and proliferative retinopathy was detected in 11 and four patients in the two groups. There was no significant excess of smokers in the group with proteinuria. Blood pressure was, however, higher in the patients with proteinuria-mean systolic pressure 161 (SD 18) mm Hg compared with 135 (19) $\mathrm{mm} \mathrm{Hg}$ (95\% confidence interval of difference between means 15 to $38 \mathrm{~mm} \mathrm{Hg}$ ); mean diastolic pressure 90 (SD 12) $\mathrm{mm} \mathrm{Hg}$ compared with 79 (15) $\mathrm{mm} \mathrm{Hg}$ (confidence interval 3 to $19 \mathrm{~mm} \mathrm{Hg}$ ). The concentration of serum high density lipoprotein (HDL) cholesterol isolated by precipitation was lower in the patients with proteinuria (confidence interval 0.02 to $0.41 \mathrm{mmol} / \mathrm{l}$ ). Their concentration of $\mathrm{HDL}_{2}$ cholesterol isolated by ultracentrifugation was also decreased (confidence interval 0.02 to $0.40 \mathrm{mmol} / \mathrm{l}$ ), whereas $\mathrm{HDL}_{3}$ cholesterol tended to be increased (confidence interval -0.01 to $0.23 \mathrm{mmol} / \mathrm{l})$. There was also a trend for serum cholesterol concentrations to be higher in the presence of proteinuria (confidence interval -0.39 to $1.20 \mathrm{mmol} / \mathrm{l}$ ).

The aggregation of risk factors for atherosclerosis in insulin dependent diabetes mellitus complicated by proteinuria helps to explain the increased prevalence of ischaemic heart disease and peripheral vascular disease reported in these patients. Early renal disease in insulin dependent diabetes may have an important role in hypertension and altered lipoprotein metabolism.
\end{abstract}

\section{Introduction}

Accelerated atherogenesis and premature cardiovascular mortality are recognised complications of diabetes. ${ }^{\prime}$ Epidemiological studies suggest that in both insulin dependent and non-insulin-dependent

University of Manchester Department of Medicine, Hope Hospital, Man-
chester
PETER H WINOCOUR, MB, MRCP, research fellow in diabetes
DAVID C ANDERSON, MD, FRCP, professor of medicine (endocrinology) and
honorary consultant physician
HAROLD COHEN, MD, FRCP, consultant physician
University of Manchester Department of Medicine, The Manchester Royal
Infirmary, Manchester
PAUL N DURRINGTON, MD, FRCP, senior lecturer in medicine and
honorary consultant physician
MONICA ISHOLA, BSC, research technician
Correspondence to: Dr Paul N Durrington, University Department of Medicine, Correspondence to: Dr Paul N Durrington,
Royal Infirmary, Manchester M13 9WL. diabetes there is an excess risk of macrovascular disease. ${ }^{1-5}$ The determinants of risk of ischaemic heart disease in the general population are cigarette smoking, hypertension, and serum low density lipoprotein (LDL) and high density lipoprotein (HDL) cholesterol concentrations. ${ }^{67}$ These risk factors operate in diabetes but provide only a partial explanation for the greatly increased likelihood of ischaemic heart disease. ${ }^{1.5}$ Indeed, in insulin dependent diabetes mellitus the serum LDL cholesterol concentration tends to be normal or low and HDL cholesterol normal or high. ${ }^{8.13}$ On the other hand, there is evidence for an abnormal lipid rich LDL or intermediate density lipoprotein in this type of diabetes ${ }^{1314}$ and, though disputed, there may be alterations in the distribution of serum HDL subfractions. ${ }^{13}{ }^{15-18}$ The relevance of either of these abnormalities to the development of atherosclerosis in insulin dependent diabetes mellitus has yet to be established. The observation from multivariate analyses, however, that serum triglycerides - which are not an independent risk factor in the general population ${ }^{19}$ - make a greater contribution to the risk of atherosclerosis in diabetes than does cholesterol ${ }^{202}$ might suggest that abnormalities of intermediate density lipoprotein or HDL are important, as both are products of the metabolism of triglyceride rich lipoproteins. ${ }^{22}$

Despite our present inability clearly to define the risk of cardiovascular disease in diabetes in terms of serum lipoprotein values, particularly in insulin dependent disease, it is established that proteinuria, which develops in nearly half of patients with insulin dependent diabetes mellitus, ${ }^{23}$ is an important determinant of premature death. ${ }^{23-25}$ Thus in one study $49 \%$ of patients with insulin dependent disease who developed proteinuria were reported to have died within seven years. ${ }^{23}$ Though many of these deaths are attributable to uraemia, ischaemic heart disease is also a significant cause. ${ }^{25}$ Patients who do not develop proteinuria resemble more closely the general population with regard to survival. ${ }^{23}$ In primary proteinuric states (other than minimal change glomerulonephritis), even in the absence of severe decreases in glomerular filtration, alterations in serum lipoprotein concentrations occur ${ }^{26}$ which may contribute to accelerated atherogenesis. ${ }^{27} \mathrm{We}$ therefore considered it important to establish the prevalence of macrovascular morbidity and risk factors for atherosclerosis in patients with insulin dependent diabetes mellitus and proteinuria, but not severe renal failure, by comparing them with patients who had not developed proteinuria.

\section{Subjects and methods}

With approval from the Salford area ethical committee 203 insulin dependent diabetics were evaluated as part of an initial assessment before entry to a large study of home blood glucose monitoring. Among these, 22 subjects $(20$ men) were identified with clinical nephropathy (persistent proteinuria of $>0.5 \mathrm{~g} /$ day $)$ but well preserved creatinine clearance $(>40 \mathrm{ml}$ $\left.\mathrm{min} / 1 \cdot 73 \mathrm{~m}^{2}\right)$ ). These patients were matched in order of importance for sex, age, duration of diabetes (to within five years except in three cases), and concentration of glycated haemoglobin $\left(\mathbf{H b A}_{1}\right)$ (to within $1 \%$ except in one case) with 22 insulin dependent diabetics out of 140 with normal albumin excretion rates. The urinary protein output and albumin excretion rate of those with clinical nephropathy were $1.35(0.4-4.5) \mathrm{g} / 24 \mathrm{~h}$ (geometric mean (range) ) and $452 \cdot 5(213 \cdot 0-961 \cdot 4) \mu \mathrm{g} / \mathrm{min}$, respectively, whereas the corresponding values for the matched control group were $0.1(0.05-0.3) \mathrm{g} / 24 \mathrm{~h}$ and $5 \cdot 3(2 \cdot 9-9 \cdot 6) \mu \mathrm{g} / \mathrm{min}$. The patients with clinical diabetic nephropathy had been diabetic for at least seven years with persistent proteinuria for a minimum of six months. None had any history or findings suggestive of nondiabetic renal disease. All subjects studied were considered to be insulin dependent, and $37(84 \%)$ had at least one previous documented episode of 
ketoacidosis. None of the subjects was taking drugs other than insulin known to affect lipoprotein metabolism or renal function. All patients were taking their usual diabetic diet, about $40 \%$ of their dietary energy coming from carbohydrate. No specific advice had been given about modifying the fat or fibre content of their diet and no patient was consuming more than $100 \mathrm{~g}$ dietary protein daily.

All participants were interviewed and examined by one of us (PHW) before evaluation of their renal function. Microvascular and macrovascular disease and tobacco and alcohol consumption were assessed. Background and proliferative retinopathy were sought by funduscopy after pupillary dilatation. Blood pressure was measured with a standard sphygmomanometer, and after a five minute rest, lying supine and seated at angles of 45 and 90 degrees. The mean of the three recordings was used in the analyses. Resting 12 lead electrocardiography was carried out. Ischaemic heart disease was classified as a history of myocardial infarction (relevant clinical history with positive electrocardiographic and cardiac enzyme evidence), typical angina pectoris (exertional central chest pain relieved by glyceryl trinitrate), or pronounced $\mathrm{Q}$ wave abnormalities or $\mathrm{T}$ wave inversion and ST segment depression, or both (Minnesota codes 1-1, 1-2, 8-1, 8-3). Definite peripheral vascular disease was diagnosed by a history of intermittent claudication associated with one or more absent foot pulses.

Blood was taken before the morning dose of insulin after patients had fasted overnight for 10-12 hours. Fasting blood glucose concentration was measured by a glucose oxidase method (Yellow Springs analyser; Clandon Scientific, United Kingdom) and $\mathrm{HbA}_{1}$ by ion exchange chromatography (Boehringer, Mannheim, West Germany). Fasting serum cholesterol and triglyceride concentrations were measured enzymatically, cholesterol by using reagent supplied by Diamed AG (Murten, Switzerland), and triglycerides by the GPO peroxidase antiperoxidase method (Boehringer, Mannheim). To isolate HDL and $\mathrm{HDL}_{3}$ by ultracentrifugation the background density of plasma was adjusted to 1063 and $1125 \mathrm{~g} / \mathrm{l}$, respectively, by adding a sodium chloride-potassium bromide solution. ${ }^{28}$ The infranatants were obtained by tube slicing (Spinco tube slicer; Beckman Instruments, Palo Alto, California) after ultracentrifugation at $100000 \mathrm{~g}$ for 48 hours (Superspeed 65 ultracentrifuge with an $18 \times 6.5 \mathrm{ml}$ sample rotor; MSE, Crawley, Sussex). HDL was also isolated by precipitation of other lipoproteins with sodium phosphotungstate and magnesium chloride. ${ }^{29}$ The concentration of cholesterol in $\mathrm{HDL}_{2}$ was determined by subtracting $\mathrm{HDL}_{3}$ cholesterol from total HDL cholesterol determined by ultracentrifugation. ${ }^{16}$ LDL cholesterol was calculated from determinations of total serum cholesterol and triglycerides and from the HDL cholesterol concentration estimated by ultracentrifugation. ${ }^{30}$ Serum apolipoprotein $\mathrm{B}$ concentrations were determined by immunoelectrophoresis using goat antiserum (Immuno; Dunton Green, Kent). ${ }^{31}$

Serum biochemical profile and urinary creatinine clearance were determined with a multichannel autoanalyser. Urinary albumin concentration was determined by an enzyme linked immunosorbent assay (ELISA; upper limit of normal $15 \mu \mathrm{g} / \mathrm{min}$ ), ${ }^{32}$ and total urinary protein by turbidimetry using benzethonium chloride routinely used in our laboratory (lower limit of detection $0.05 \mathrm{~g} / \mathrm{l}$ ). Creatinine clearance (corrected for body surface area), albumin excretion rate, and urinary protein excretion were calculated from 24 hour urine collections.

Statistics-The data in the two groups were compared by unpaired Student's $t$ test for normally distributed variables or Wilcoxon's sum rank squares test if non-Gaussian. The significance of the prevalence of microvascular and macrovascular disease was assessed by Fisher's two sided exact test.

\section{Results}

The groups with proteinuria and normal albumin excretion rates were similar with regard to age, age at onset and duration of diabetes, body mass (Quetelet's) index, and insulin dose (table I). There was no excess of smokers or difference in alcohol consumption in those with proteinuria. Glycaemic control (as assessed by fasting blood glucose and $\mathrm{HbA}_{1}$ values) and serum albumin concentrations were similar in the two groups. The patients with proteinuria had on average moderately increased serum urea $(p<0.02)$ and creatinine $(p<0.005)$ concentrations. Their creatinine clearance was not reduced significantly (table I).

Macrovascular disease (ischaemic heart disease or peripheral vascular disease, or both) was significantly more prevalent in patients with proteinuria $(p<0.05)$ (table II). Retinopathy was present in 15 patients in each group, but proliferative retinopathy was more frequent in those with proteinuria $(p<0.05)$. Systolic and diastolic blood pressures were higher in the patients with proteinuria $(p<0.0001$ and $p<0.02$, respectively).

Concentrations of serum cholesterol, serum triglycerides, LDL cholesterol, and apolipoprotein $\mathrm{B}$ and the mass ratio of LDL cholesterol to apolipoprotein B tended to be higher in patients with proteinuria but without reaching levels of significance, though the increased total serum
TABLE I-Characteristics of insulin dependent diabetics with normal albumin excretion rate or proteinuria. Except where stated otherwise values are means with $S D$ in parentheses

\begin{tabular}{|c|c|c|}
\hline & $\begin{array}{l}\text { Normal albumin } \\
\text { excretion rate }\end{array}$ & Proteinuria \\
\hline No (sex) of patients & $22(20 \mathrm{M}, 20 \mathrm{~F})$ & $22(20 \mathrm{M}, 2 \mathrm{~F})$ \\
\hline Age (years) & $44 \cdot 2 \cdot(13 \cdot 6)$ & $43 \cdot 7(13 \cdot 7)$ \\
\hline Age at onset of diabetes (years) & $25 \cdot 2(13 \cdot 6)$ & $23 \cdot 8(14 \cdot 4)$ \\
\hline Duration of diabetes (years) & $19 \cdot 1(8 \cdot 4)$ & $20 \cdot 0(8 \cdot 5)$ \\
\hline Body mass (Quetelet's) index & $24 \cdot 1(3 \cdot 3)$ & $25 \cdot 1(3 \cdot 7)$ \\
\hline Insulin dose (units/day) & $51(14)$ & $56(18)$ \\
\hline No of smokers & 6 & 8 \\
\hline Median weekly alcohol consumption (g) (range) & $48(0-240)$ & $64(0-640)$ \\
\hline Median fasting blood glucose $(\mathrm{mmol} / \mathrm{l})$ (range $)$ & $11 \cdot 4(3 \cdot 0-26 \cdot 7)$ & $9 \cdot 6(1 \cdot 3-24 \cdot 5)$ \\
\hline $\mathrm{HbA}_{1}(\%)$ & $8 \cdot 9(1 \cdot 5)$ & $8 \cdot 7(1 \cdot 0)$ \\
\hline Serum urea $(\mathrm{mmol} / \mathrm{l})$ & $5 \cdot 6(1 \cdot 5)$ & $7 \cdot 2(2 \cdot 5)^{\star}$ \\
\hline Serum creatinine $(\mu \mathrm{mol} / \mathrm{l})$ & $91(12)$ & $112(30)^{\star \star}$ \\
\hline Creatinine clearance $\left(\mathrm{ml} / \mathrm{min} / 1 \cdot 73 \mathrm{~m}^{2}\right)$ & $105(29)$ & $92(34)$ \\
\hline Serum albumin $(g / l)$ & $43(2)$ & $42(3)$ \\
\hline
\end{tabular}

${ }^{\star} \mathrm{p}<0.02 . \quad{ }^{\star \star} \mathrm{p}<0.005$.

TABLE II-Clinical features of insulin dependent diabetics with normal albumin excretion rate or proteinuria

\begin{tabular}{lcc}
\hline & $\begin{array}{c}\text { Normal albumin } \\
\text { excretion rate }\end{array}$ & Proteinuria \\
\hline $\begin{array}{l}\text { No with macrovascular disease (ischaemic heart disease } \\
\text { or peripheral vascular disease, or both) }\end{array}$ & 3 & $10^{\star}$ \\
No with ischaemic heart disease & 2 & $8^{\star}$ \\
No with peripheral vascular disease & 2 & $8^{\star}$ \\
No with background retinopathy & 11 & $4^{\star}$ \\
No with proliferative retinopathy & 4 & $11^{\star}$ \\
Mean systolic blood pressure (mm Hg)(SD) $\dagger$ & $135(19)$ & $161(18)^{\star \star \star}$ \\
Mean diastolic blood pressure (mm Hg)(SD) & $79(15)$ & $90(12)^{\star \star}$ \\
\hline
\end{tabular}

${ }^{\star} \mathrm{p}<0.05 .{ }^{\star \star} \mathrm{p}<0.02 .{ }^{\star \star \star} \mathrm{p}<0.0001$.

$+95 \%$ Confidence interval of difference between means 15 to $38 \mathrm{~mm} \mathrm{Hg}$.

$\ddagger 95 \%$ Confidence interval of difference between means 3 to $19 \mathrm{~mm} \mathrm{Hg}$.

TABLE III-Lipids and lipoproteins in insulin dependent diabetics with normal albumin excretion rate or with proteinuria. Except where stated otherwise values are means with $S D$ in parentheses

\begin{tabular}{|c|c|c|}
\hline & $\begin{array}{l}\text { Normal albumin } \\
\text { excretion rate }\end{array}$ & Proteinuria \\
\hline $\begin{array}{l}\text { Triglycerides (mmol/l) (geometric mean } \\
\text { (range)) }\end{array}$ & $1 \cdot 27(0 \cdot 68-2 \cdot 39)$ & $1.48(0.81-2 \cdot 70)$ \\
\hline Cholesterol $(\mathrm{mmol} / \mathrm{l}) \dagger$ & $5.51(1 \cdot 25)$ & $6.13(1.44)$ \\
\hline LDL cholesterol $(\mathrm{mmol} / \mathrm{l})$ & $3 \cdot 39(1 \cdot 17)$ & $3.84(1.52)$ \\
\hline Apolipoprotein B (mg/dl) & $107 \cdot 1(36 \cdot 1)$ & $111 \cdot 1(31 \cdot 6)$ \\
\hline LDL cholesterol/apolipoprotein $B^{\star}$ & $1.31(0.49)$ & $1.42(0.62)$ \\
\hline $\mathrm{HDL}_{\mathrm{uc}}$ cholesterol $(\mathrm{mmol} / \mathrm{l})$ & $1.49(0.39)$ & $1 \cdot 38(0.26)$ \\
\hline $\mathrm{HDL}_{\mathrm{p}}$ cholesterol $(\mathrm{mmol} / \mathrm{l}) \ddagger$ & $1.46(0.37)$ & $1.24(0.25)^{\star \star}$ \\
\hline $\mathrm{HDL}_{3 \mathrm{uc}}$ cholesterol $(\mathrm{mmol} /)^{\natural}$ & $0.69(0.21)$ & $0.79(0.22)$ \\
\hline $\mathrm{HDL}_{2 \mathrm{uc}}$ cholesterol $(\mathrm{mmol} / \mathrm{l})^{9}$ & $0.80(0.35)$ & $0.59(0.27)^{\star \star}$ \\
\hline $\mathrm{HDL}_{\mathrm{uc}} / \mathrm{LDL}_{\mathrm{uc}}$ cholesterol & $0.50(0.23)$ & $0.42(0 \cdot 20)$ \\
\hline
\end{tabular}

$\mathrm{HDL}_{\mathrm{uc}}$ Refers to ultracentrifugation data. $\mathrm{HDL}_{\mathrm{pl}}$ Refers to precipitation data.

${ }^{\star} \mathrm{LDL}$ cholesterol converted to $\mathrm{mg} / \mathrm{dl}$ for calculation of ratio.

$\star \star \mathrm{p}=0.03$.

$+95 \%$ Confidence interval -0.39 to $1.20 \mathrm{mmol} / \mathrm{l}$

$\ddagger 95 \%$ Confidence interval 0.02 to $0.41 \mathrm{mmol} / 1$.

$95 \%$ Confidence interval -0.01 to $0.23 \mathrm{mmol} / 1$.

I $95 \%$ Confidence interval 0.02 to $0.40 \mathrm{mmol} / \mathrm{l}$.

cholesterol concentration was close $(\mathrm{p}<0 \cdot 1 ; 95 \%$ confidence interval -0.39 to $1 \cdot 20 \mathrm{mmol} / \mathrm{l}$ ) (table III).

Total HDL cholesterol concentrations did not differ significantly when isolated by ultracentrifugation, but the value was decreased in patients with proteinuria when precipitation was used $(p=0.03)$. There was also a significant reduction in the concentration of cholesterol in the $\mathrm{HDL}_{2}$ subfraction determined by ultracentrifugation $(p=0.03)$ with a suggestively higher concentration of cholesterol transported in $\mathrm{HDL}_{3}(\mathrm{p}=0.08 ; 95 \%$ confidence interval -0.01 to $0.23 \mathrm{mmol} / \mathrm{l}$ ) in patients with proteinuria.

\section{Discussion}

We have shown in a case-control study that insulin dependent diabetics with proteinuria, even in the absence of renal failure, have a higher prevalence of atherosclerotic disease than do those with a 
normal albumin excretion rate and renal function. This was associated with significantly higher systolic and diastolic blood pressure and reduced concentrations of serum $\mathrm{HDL}$ and $\mathrm{HDL}_{2}$ cholesterol and a tendency for increased concentrations of serum $\mathrm{HDL}_{3}$ and total cholesterol. The LDL cholesterol to apolipoprotein B mass ratio was increased to a similar degree in both proteinuric and non-proteinuric patients, confirming observations that a less dense LDL, possibly intermediate density lipoprotein, is found in insulin dependent diabetes mellitus. ${ }^{1314}$ Cigarette smoking was similar in both groups and so did not account for the difference in macrovascular complications.

Increased cardiovascular mortality has been reported to accompany the development of proteinuria in insulin dependent diabetes mellitus. ${ }^{25}$ As patients who did not develop proteinuria were found to have almost normal life expectancy, ${ }^{2325}$ most patients with insulin dependent disease who develop premature atherosclerosis are likely to have proteinuria. The reason for this association, which was previously unknown, now seems likely to be due to an aggregation of risk factors for atherosclerotic disease. Other studies have suggested that there is an increase in blood pressure in insulin dependent diabetes mellitus during the phase of microalbuminuria, even before progression to the stage of overt proteinuria, present in our patients. ${ }^{33-35}$ This may lead to an early increase in the transcapillary escape of albumin..$^{36} \mathrm{~A}$ concomitant increase in the transcapillary escape of other macromolecules might be expected to accelerate atheroma by facilitating the entry of lipoproteins and other atherogenic blood components into the arterial wall. ${ }^{37}$

In addition to our findings, patients with insulin dependent diabetes mellitus and proteinuria may be more prone to atherosclerotic vascular complications by virtue of the enhanced platelet adhesion, ${ }^{25}$ higher blood viscosity, ${ }^{38}$ and raised plasma fibrinogen concentrations $^{39}$ associated with the development of nephropathy.

There have been previous studies of serum lipoprotein concentrations in insulin dependent diabetes mellitus complicated by albuminuria ( $>150 \mu \mathrm{g} / \mathrm{min}$ ) which, compatible with our findings, were associated with increases in serum triglyceride values, total and LDL cholesterol and apolipoprotein B concentrations, and a decrease in total serum HDL cholesterol isolated by precipitation of other lipoproteins with phosphotungstate and magnesium..$^{40} \mathrm{We}$ have extended these studies by combining similar observations with an investigation of vascular morbidity, blood pressure, and HDL subfractions.

Our finding that total HDL cholesterol concentrations were lower when isolated by phosphotungstate and magnesium precipitation rather than by ultracentrifugation confirms our earlier observation. ${ }^{42}$ That the different HDL cholesterol concentration by the two methods was most pronounced in patients with proteinuria suggests that a change in the composition of HDL associated with nephropathy might account for the disparity. We know, for example, that the lipoprotein $\mathrm{Lp}(\mathrm{a})$ has a hydrated density which overlaps with $\mathrm{HDL}_{2}{ }^{43}$ but that because of its apolipoprotein $\mathrm{B}$ content it may precipitate with phosphotungstate. As high concentrations of $\mathrm{Lp}(\mathrm{a})$ have been linked with coronary heart disease,${ }^{43}$ this aspect of HDL composition in diabetes may be of considerable interest.

There has been dispute about whether serum cholesterol in $\mathrm{HDL}_{3}{ }^{131618}$ or $\mathrm{HDL}_{2}^{17}$ is increased in insulin dependent diabetes mellitus. Our finding that $\mathrm{HDL}_{3}$ cholesterol tends to be increased and $\mathrm{HDL}_{2}$ significantly decreased in patients with proteinuria compared with those with normal albumin excretion rates is thus particularly interesting, as it suggests that differences in renal function may account for some of the opposing findings by different study groups. Similar findings have been made in non-diabetic patients with primary renal disease associated with proteinuria. ${ }^{26}$ In those patients there was greatly increased urinary loss of the apolipoprotein AI, which was dependent on the selectivity of the renal protein leak and the severity of proteinuria. In that study of primary proteinuric states most patients had higher urinary protein excretion than did our patients with proteinuria. In diabetes, however, possibly the glomerular basement membrane poses less resistance to the filtration of free apolipoprotein $\mathrm{AI}$ and smaller molecular weight $\mathrm{HDL}$ species, such as $\mathrm{HDL}_{3}$, either because of alterations in the electrical charge of the glomerular basement membrane owing to glycation or changes in its glycosaminoglycan composition $^{44}$ or because of glycation of apolipoprotein AI itself. Glycation of apolipoprotein AI enhances its catabolism, ${ }^{45}$ and in rats there is evidence that the kidney is a main site of apolipoprotein AI catabolism, the proximal convoluted tubule cells degrading apolipoprotein $\mathrm{AI}$ entering the urine space. ${ }^{46}$ Already some evidence suggests that even in health the kidney may have a similar role in man. ${ }^{47}$ There is a wealth of evidence that the diseased kidney may have a more profound effect on lipoprotein metabolism. ${ }^{48}$

The $\mathrm{HDL}_{3}$ molecule (mean diameter $55 \AA$ ) is the precursor of the larger $\mathrm{HDL}_{2}$ molecule (mean diameter $85 \AA$ ). We have proposed that in the nephrotic syndrome the increased serum $\mathrm{HDL}_{3}$ concentration is due to increased production; however, because of the smaller size of $\mathrm{HDL}_{3}$ it is more readily lost into the urine before it has circulated long enough to acquire sufficient cholesterol to become $\mathrm{HDL}_{2}{ }^{26} \mathrm{~A}$ similar mechanism may operate in insulin dependent diabetes mellitus, the production of HDL being accelerated by the rapid lipolysis of triglyceride rich lipoproteins which are themselves secreted at an abnormally high rate. ${ }^{49}$ Lipoprotein lipase activity is raised in diabetics receiving systemic insulin treatment. ${ }^{9}$ The HDL thus produced may, however, be catabolised more rapidly than normal owing to glycation and in patients with nephropathy by increased urinary loss, particularly of the smaller $\mathrm{HDL}_{3}$ species, perhaps before they can be converted to larger $\mathrm{HDL}_{2}$ particles.

In addition to the association of proteinuria with an increased prevalence of macrovascular disease, this study provides further evidence for a link between nephropathy, hypertension, and proliferative retinopathy ${ }^{50}$ Some workers have concluded that the common factor underlying the association between renal and retinal microangiography is cigarette smoking..$^{51.53}$ In our study, however, the association between proteinuria and proliferative retinopathy was evident even though cigarette smoking was as common in patients without proteinuria. An alternative possibility is that the lipoprotein abnormalities described here and in earlier reports ${ }^{3854}$ may have a role in the propagation of microvascular disease secondary to their accumulation in mesangial cells. This may in turn lead to proliferation and increased synthesis of basement membrane glycosylaminoglycans, as has been proposed in primary renal disease. ${ }^{55}$

We conclude that the effects of early nephropathy on lipoprotein metabolism in diabetes in particular may have been neglected. Our study and that of Vannini $e t a l^{40}$ suggest that there are cogent reasons further to elucidate the role of the kidney in lipoprotein metabolism in insulin dependent diabetes mellitus. We have shown that patients with insulin dependent diabetes mellitus and proteinuria have an increased prevalence of macrovascular disease with an associated excess of known cardiovascular risk factors. In practical terms efforts to reduce the excessive mortality in insulin dependent diabetes mellitus from ischaemic heart disease should therefore be focused on patients with proteinuria, who may benefit most from intensive management with antihypertensive and lipid modifying agents.

We thank Mrs $H$ Dhar and Dr P Kalsi for measurement of albumin excretion rates, the staff of the department of chemical pathology, Hope Hospital, for routine biochemical assessments, Miss L Hunt for help in statistical analysis, and Ms J Rostron for expert secretarial work. PHW is supported by a grant from the North West Regional Health Authority. This study also received financial assistance from Eli Lilly and Co Ltd and the Central Manchester Health Authority.

\section{References}

1 Garcia MJ, McNamara PM, Gordon T, Kannel WB Morbidity and mortality in diabetics in the Framingham population. Sixteen year follow up study. Diabetes 1974;23:105-11.

2 Kessler LI. Mortality experience of diabetic patients. A twenty-six year follow-up studv. Am Med 1971;51:715-24.

Pirart J. Diabetes mellitus and its degenerative complications: a prospective study of 4400 patients observed between 1947 and 1973. Diabetes Care 1978;1:168-88, 252-63.

4 Kannel WB, McGee DL. Diabetes and cardiovascular risk factors: the Framingham study Circulation 1979;59:8-12.

Jarrett KJ, Shipley MJ. Mortality and associated risk factors in diabetics. Acta Endocrinol 1985;110(suppl 272):21-6. 
6 Dawber TR. The Framingham study: the epidemiology of atherosclerotic disease. Cambridge, Massachusetts: Harvard University Press, 1980.

7 Brunzell JD, Miller NE. Atherosclerosis in inherited and acquired disorders of plasma lipoprotein metabolism. In: Miller NE, Lewis B, eds. Lipoproteins, atherosclerosis and coronary hear disease. Amsterdam: Elsevier North Holland Biomedical Press, 1981:73-88.

8 Kennedy AL, Lappin TRJ, Lavery TD, Hadden DR, Weaver JA, Montgomery DAD. Relation of high-density lipoprotein cholesterol concentration to type of diabetes and its control.
ond of high-density lipoprotein
$B r M e d ~ \mathcal{~} 1978 ; i i: 1191-4$.

9 Nikkila EA, Hormila P. Serum lipids and lipoproteins in insulin-treated diabetics. Demonstration of increased high density lipoprotein concentrations. Diabetes 1978;27:1078-85.

10 Mattock MB, Fuller JH, Maude PS, Keen H. Lipoprotein and plasma cholesterol esterification in normal and diabetic subjects. Atherosclerosis 1979;34:439-49.

11 Durrington PN. Serum high density lipoprotein cholesterol in diabetes mellitus: an analysis of factors which influence its concentration. Clin Chim Acta 1980;104:11-23.

12 Sosenko JM, Breslow JL, Mieltenen DS, Gabbay KH. Hyperglycemia and plasma lipid levels: a prospective study of young insulin dependent diabetic patients. N Engl I Med 1980;302:650-4.

13 Winocour PH, Durrington PN, Ishola M, Anderson DC. Lipoprotein abnormalities in insulindependent diabetes mellitus. Lancet 1986;i:1176-8.

14 Schonfeld G, Birge C, Miller JP, Kellser G, Santiago J. Apolipoprotein B levels and altered lipoprotein composition in diabetes. Diabetes 1974;23:927-34.

15 Nikkila EA. High density lipoprotein in diabetes. Diabetes 1981;30:82-7.

15 Nikkila EA. High density lipoprotein in diabetes. Diabetes $1981 ; 30: 82-7$.
16 Durrington PN. Serum high density lipoprotein cholesterol subfractions in type 1 (insulindependent) diabetes mellitus. Clin Chim Acta 1982;120:21-8.

17 Mattock MB, Salter AM, Fuller JH, et al. High density lipoprotein subfractions in insulindependent diabetic and normal subjects. Atherosclerosis 1982;45:67-9.

18 Cruickshank KJ, Orchard TJ, Becker DJ. The cardiovascular risk profile of adolescents with insulin dependent diabetes mellitus. Diabetes Care 1985;8:118-24.

19 Hulley SB, Rosenmann BH, Bawol RD, Brand JJ. The association between triglyceride and coronary heart disease. $N$ Engl f Med 1980;302:1383-9.

20 West KM, Ahuja MMS, Bennett PH, et al. The role of circulating glucose and triglyceride concentrations and their interaction with other "risk factors" as determinants of arterial disease in nine diabetic population samples from the WHO multinational study. Diabetes Care 1983;6:361-9.

21 Janka HV. Five year incidence of major macrovascular complications in diabetes mellitus. In Janka HV, Mehnert $\mathrm{H}$, Standl $\mathrm{E}$, eds. Macrovascular disease in diabetes mellitus, pathogenesis and prevention. Stuttgart, New York: Georg Thieme, 1985:16-9.

22 Havel RJ, Goldstein JL, Brown MS. Lipoproteins and lipid transport. In: Bondy PK, Rosenberg LE, eds. Metabolic control and disease. Philadelphia: W B Saunders, 1980:393-494.

23 Andersen AR, Christiansen JS, Andersen JK, Kreiner S, Deckert T. Diabetic nephropathy in type 1 (insulin dependent) diabetes mellitus: an epidemiological study. Diabetologia 1983;25: 496-501.

24 Viberti GC, Hill RD, Jarrett RJ, Argyropoulus A, Mahmud U, Keen H. Microalbuminuria as a predictor of clinical nephropathy in insulin-dependent diabetes mellitus. Lancet 1982;i:1430-2.

25 Borch-Johnsen K, Andersen PK, Deckert T. The effect of proteinuria on relative mortality in type 1 (insulin-dependent diabetes mellitus). Diabetologia 1985;28:590-6.

26 Short CD, Durrington PN, Mallick NP, Hunt LP, Tetlow L, Ishola M. Serum and urinary high density lipoproteins in glomerular disease with proteinuria. Kidney Int 1986;29:1224-8.

27 Mallick NP, Short CD. The nephrotic syndrome and ischaemic heart disease. Nephron 1981;27:54-7.

28 Havel RJ, Eder HA, Bragdon JH. The distribution and chemical composition of ultracentrifugally separated lipoproteins in normal serum. f Clin Invest 1955;34:1345-53.

29 Burstein M, Scholnick HR, Morfin R. Rapid method for the isolation of lipoproteins from human serum by precipitation with polyanions. $\mathcal{F}$ Lipid Res 1970;11:583-95.
30 Friedewald WT, Levy R, Fredrickson DS. Estimations of serum low density lipoprotein cholesterol without use of preparative ultracentrifuge. Clin Chem 1972;18:499-502.

31 Durrington PN, Whicher JT, Warren C, Bolton CH, Hartog M. A comparison of methods for the immuoassay of serum apolipoprotein B in man. Clin Chim Acta 1972;71:95-108.

32 Fielding BA, Price DA, Houlton CA. Enzyme immunoassay for urinary albumin. Clin Chem 1983;29:355-7.

33 Wiseman M, Viberti G, Macintosh D, Jarrett RJ, Keen H. Glycaemia, arterial pressure and microalbuminuria in type 1 (insulin-dependent) diabetes mellitus. Diabetologia 1984;26:401-5.

34 Mathiesen ER, Oxenboll B, Johansen K, Svendsen PAa, Deckert T. Incipient nephropathy in type 1 (insulin-dependent) diabetics. Diabetologia 1984;26:406-10.

35 Hasslacher $\mathrm{Ch}$, Stech W, Wahl P, Ritz E. Blood pressure and metabolic control as risk factors for nephropathy in type 1 (insulin-dependent) diabetes. Diabetologia 1985;26:6-11.

36 Feldt-Rasmussen B. Increased transcapillary escape rate of albumin in type 1 (insulin-dependent) diabetic patients with microalbuminuria. Diabetologia 1986;29:282-6.

37 Ross R. The pathogenesis of atherosclerosis: an update. N Englf Med 1986;314:418-22.

38 Skovborg F. Blood viscosity in normal and diabetic subjects. A clinical-hemorrheological study. Copenhagen: Fad's Forlag, 1974. (PhD thesis.)

39 Valdorf-Hansen W. Coagulability in diabetics. Acta Med Scand 1967;476(suppl);147-57.

40 Vannini $P$, Giavarella A, Flammini $M$, et al. Lipid abnormalities in insulin-dependent diabetic patients with albuminuria. Diabetes Care 1984;7:151-4.

41 Eckel RH, McLean E, Albers JJ, Cheung MC, Bierman EL. Plasma lipids and microangiopathy in insulin-dependent diabetes mellitus. Diabetes Care 1981;4:447-53.

42 Durrington PN. A comparison of three methods of measuring serum high density lipoprotein cholesterol in diabetics and non-diabetics. Ann Clin Biochem 1980;17:199-204.

43 Kostner GM. Lipoprotein $L p(a)$ in man: structure, metabolism and myocardial infarction risk. In: Crepaldi G, LeFebre PJ, Galton DJD, eds. Diabetes, obesity and hyperlipidaemia II. London: Academic Press, 1983:9-14.

44 Kverneland A, Feldt-Rasmussen B, Vidal P, et al. Evidence of changes in renal charge selectivity in patients with type 1 (insulin-dependent) diabetes mellitus. Diabetologia 1986;29:634-9.

45 Witztum JL, Fisher M, Metro T, Steinbrecher V, Glam RI. Non-enzymatic glycosylation of high density lipoprotein accelerates its catabolism in guinea pigs. Diabetes 1982;31:1029-34.

46 Glass CK, Pittman RC, Keller GA, Steinberg D. Tissue sites of degradation of apoprotein A-I in the rat. $\mathcal{F}$ Biol Chem 1983;258:7161-7.

47 Segal P, Gidez LI, Vega G, Edelstein D, Eder HA, Roheim PS. Apoproteins of high density lipoproteins in the urine of normal subjects. $f$ Lipid Res 1979;20:784-8.

48 Shore VG, Forte T, Licht H, Lewis SB. Serum and urinary lipoproteins in the human nephrotic syndrome: evidence for renal catabolism of lipoproteins. Metabolism 1982;31:258-68.

49 Nikkila EA. Triglyceride metabolism in diabetes mellitus. Prog Biochem Pharmacol 1973;8: 271-99.

50 Parving HH, Andersen AR, Smidt UM, Oxenboll B, Edsberg G, Christiansen JS. Diabetic nephropathy and arterial hypertension. Diabetologia 1983;24:10-2.

51 Telmer S, Christiansen JS, Andersen AR, Nerup J, Deckert T. Smoking habits and prevalence of clinical diabetic microangiopathy in insulin-dependent diabetics. Acta Med Scand 1984;215: 63-8.

52 Nielsen MM, Hiøllund E. Smoking and diabetic microangiopathy. Lancet 1978;ii:533-4.

53 Mulhauser I, Sawicki P, Berger M. Cigarette smoking as a risk factor for macroproteinuria and proliferative retinopathy in type 1 (insulin-dependent) diabetes. Diabetologia 1986;29:500-2.

54 Dornan TL, Carter RD, Bron AJ, Turner RC, Mann JI. Low density lipoprotein cholesterol: an association with the severity of diabetic retinopathy. Diabetologia 1982;22:167-70.

55 Moorhead JF, Chan MK, El-Nahas M, Varghese Z. Lipid nephrotoxicity in chronic progressive glomerular and tubulo-interstitial disease. Lancet 1982;ii:1309-11.

(Accepted 27 March 1987)

\title{
Proteinuria: value as predictor of cardiovascular mortality in insulin dependent diabetes mellitus
}

\author{
KNUT BORCH-JOHNSEN, SVEND KREINER
}

\section{Abstract}

The relation between diabetic microangiopathy and macroangiopathy was studied by analysing the relative mortality from cardiovascular disease in patients with insulin dependent diabetes mellitus with and without persistent proteinuria. The study group comprised 2890 diabetics diagnosed between 1933 and 1972 before the age of 31 , and the study was conducted by using the linear logistic discrete failure time model. In patients with proteinuria the relative mortality from cardiovascular disease was 37 times that in the general population; in patients without

Steno Memorial Hospital, DK-2820 Gentofte, Denmark

KNUT BORCH-JOHNSEN, MD, research fellow

Department of Data Processing, Copenhagen County Hospital, DK-2730 Herlev, Denmark

SVEND KREINER, MSC, statistical consultant

Correspondence to: Dr Borch-Johnsen. proteinuria it was $4 \cdot 2$ times that in the general population. In both groups women had a relative mortality twice to 2.6 times that of men. In neither group was relative mortality correlated with duration of diabetes, suggesting that the association between diabetes and cardiovascular disease may be conferred by factors other than hyperglycaemia and hyperinsulinaemia.

The high relative mortality from cardiovascular disease in diabetics with proteinuria indicates a strong association between diabetic microangiopathy and macroangiopathy, suggesting a common (pathogenetic?) mechanism for these two late diabetic complications.

\section{Introduction}

Insulin dependent diabetes is characterised by a high relative mortality, ${ }^{1}$ which recent studies have shown is confined almost entirely to patients developing persistent proteinuria. ${ }^{2}$ Furthermore, mortality from cardiovascular disease also tends to be higher in patients with proteinuria than in those without. ${ }^{2}$ Previous studies 